\title{
Current and Prospective Strategies in the Varietal Improvement of Chilli (Capsicum annuum L.) Specially Heterosis Breeding
}

\author{
K. M. Rezaul Karim ${ }^{1}$, Mohd Y. Rafii ${ }^{1, *} \mathbb{1}$, Azizah Binti Misran ${ }^{2}$, Mohd Firdaus Bin Ismail ${ }^{2}$, Abdul Rahim Harun ${ }^{3}$, \\ Md Mahmudul Hasan Khan ${ }^{1}$ (D) and Mst. Farhana Nazneen Chowdhury ${ }^{2}$ \\ 1 Laboratory of Climate-Smart Food Crop Production, Institute of Tropical Agriculture and Food Security, \\ Universiti Putra Malaysia (UPM), Serdang 43400, Malaysia; bsrirezaulg@gmail.com (K.M.R.K.); \\ mhasan.bari12@gmail.com (M.M.H.K.) \\ 2 Department of Crop Science, Faculty of Agriculture, Universiti Putra Malaysia (UPM), Serdang 43400, \\ Malaysia; azizahm@upm.edu.my (A.B.M.); mohd.firdaus@upm.edu.my (M.F.B.I.); \\ farhananazneen80@gmail.com (M.F.N.C.) \\ 3 Agrotechnology and Bioscience Divisions, Malaysian Nuclear Agency, Bangi, Kajang 43600, Malaysia; \\ rahim@nm.gov.my \\ * Correspondence: mrafii@upm.edu.my; Tel.: +60-193096876
}

\section{check for} updates

Citation: Karim, K.M.R.; Rafii, M.Y.; Misran, A.B.; Ismail, M.F.B.; Harun, A.R.; Khan, M.M.H.; Chowdhury, M.F.N. Current and Prospective Strategies in the Varietal Improvement of Chilli (Capsicum annuum L.) Specially Heterosis Breeding. Agronomy 2021, 11, 2217. https://doi.org/10.3390/ agronomy11112217

Academic Editor: Md Asaduzzaman

Received: 21 September 2021

Accepted: 14 October 2021

Published: 1 November 2021

Publisher's Note: MDPI stays neutral with regard to jurisdictional claims in published maps and institutional affiliations.

Copyright: (c) 2021 by the authors. Licensee MDPI, Basel, Switzerland. This article is an open access article distributed under the terms and conditions of the Creative Commons Attribution (CC BY) license (https:// creativecommons.org/licenses/by/ $4.0 /)$

\begin{abstract}
Chilli (Capsicum annuum L.) is an herbaceous crop and plays an important role as common spices and vegetables. Pepper (Capsicum spp.) is one of the most cost-effective and agricultural vegetables in the world. The most significant characteristics of peppers, as spices and in various pharmacological uses, are pungency and oleoresin (color). Cabsicum annuum L. is widely used as a medicinal herb and in the Mediterranean diet (at the present, $C$. annuum var. acuminatum Fingerh. and Capsicum frutescens L. are considered synonyms of C. annuum L.). Capsicum annuum includes a wide range of carotenoids including capsanthin, capsorubin, beta-carotene, cryptoxanthin, lutein, fanthophyl, and xanthophyll, and capsaicinoid. However, it remains limited in production due to the lack of development in varieties especially under severe climatic circumstances such as drought, high temperature, or salt. Some reports were provided through distinct traditional approaches for genetic improvement. A combination of traditional and molecular breeding, especially breeding for heterosis, might be a good option for developing a novel genotype for ecologically adversely affected niche adaption. This review summarizes the current chilli breeding approaches with their drawbacks and highlights some recent classical efforts for the improvement of the crop. This would be the milestone for the breeders in the planning of a successful chilli breeding program to combat the adverse ecological condition. Thus, the information gathered in this article might be considered as the cornerstone of Chilli breeders at their ongoing and sustainable future programs as well.
\end{abstract}

Keywords: Capsicum annuum L.; varietal improvement; heterosis; breeding techniques

\section{Introduction}

The Chilli (Capsicum annuum L.) is the most important species and is used as a vegetable all over the world [1]. It is a popular crop in tropical Asia and equatorial America, with a wide genetic diversity, due to its delicious and pungent fruit with excellent nutritional contents. [2]. Whether Chilli is consumed fresh or dried form they keep an important role to add nutrients to our diet [3]. It also reduces obesity as well as diabetes for its capsaicin. Furthermore, as it contains different vitamins such as vitamin A, B6, and C, along with antioxidants and nutrients such as calcium, zinc, and iron, it protects eyes, skins, hearts from dysfunctions [4]. Cosmetics and pharmaceuticals factories are using extracts of chilli for various purposes. Mainly its potentiality as a spice and has aesthetic demand as they can be cultivated in tubs or smallholding gardens [5].

Chilli is a member of the Solanaceae family's Capsicum genus, which contains 30 species, including Capsicum annuum L. (hot and sweet peppers), Capsicum frutescens L. (bird pepper), 
Capsicum chinense Jacq. (Fragrant chilli pepper), Capsicum baccatum L. (aji), and Capsicum pubescens Ruiz and Pav. (rocoto) are domesticated all over the world. Among them, C. annuum L., C. frutescens L., and C. chinense Jacq are developed in both tropical and temperate zones. However, C. annuиm L. is the most popular and cultivated species for different types thereof [6]. The Capsicum species are diploid with chromosome number $2 n=2 x=24$ with a genomic size of $2700 \mathrm{Mb}$ and 30,701 genes even though certain species have chromosome number $2 n=2 x=26$ and are closely related to other Solanaceae crops such as potato, tomato, and eggplant $[7,8]$.

The interest of researchers about the Capsicum is increasing day by day as there is a lot of diversity for many of the traits of this crop, for instance, plant morphology, flower architecture, bearing types, colours, spiciness, and qualitative characteristics. Thus this Chilli has extremely diverse and suitable for various kinds of uses, especially in research. The presence of sweet and hot-type capsicum has created an opportunity to be used in many ways as a food item. Some peppers are mainly eaten as vegetables, either raw or cooked, in temperate regions of Europe and North America. The spicy ones are generally found in America's tropical regions, Africa and Asia, where they are used as a condiment and spice in a variety of cooking, both fresh and dried. The following types of pepper used for food might be described: (a) direct use of premature green fruits, ripen fruits, and leaves; (b) fresh fruit collection to process for sauces, pastes, pickles, beer, and other drinks; and (c) dried spices and powder manufactured from maturing fruits. More than 20 market types are regularly available on the market depending on fruit shape (for example, jalapeo, cayenne, bell, ancho, pasilla, hungarian wax, jwala, and Thai) [9].

Chilli adds a crucial taste to the curry of the tropical world as it gives a fiery taste and acuity to the food preparation. Chilli is additionally the wellspring of proteins, starches, minerals, ascorbic corrosive, sugars, and different cancer prevention agents. Global interest in Chilli as a business crop is expanding constantly. Along these lines, it is vital to upgrade chili production quickly to satisfy up this worldwide need while improving its nutritional and medicinal advantages [10].

Due to the scanty local production and yield, a large number of countries are to import Chilli from other countries. Improvement of high-yielding varieties is one of the main considerations to increase production. Quite possibly the main component for extending of production area is the prerequisite of high-yielding assortments. Consequently, several breeding projects have been carried out to increase the production of the crop [11-13]. To increase the current productivity of chilli as a vegetable crop less consideration has been paid to hereditary improvement. Utilizing the indigenous inferior quality cultivars with diminished resistance of open-pollinated genotypes against biotic stresses, are liable for low profitability [10]. To stay away from hereditary disintegration, it is essential to utilize existing genetic materials, the profitability chilli couldn't be earned by utilizing open-pollinated varieties. Identification, and utilization, of appropriate parental lines, are fundamental for developing possible hybrids of chilli with high and stable yield. Moreover, improving yield, quality, and tolerance to cope with biotic and abiotic stress at the same time is a critical need of time [14].

In a hybrid development strategy, genetic diversity linked with combining ability is a criterion for selecting parents. At the point of crossing intersection among highly related parents then a low increase of heterosis is noticed, however high heterosis happens when the cross is made between parents of greater dissimilarity [13] and [11]. In the advance line selection process, heterotic group identification, pattern identification, and analysis of combining ability of sets of inbred lines play a significant role in chilli breeding [12] and [11]. At the same time, many studies have been conducted using heterosis breeding to increase chilli yield and quality traits $[11,15,16]$.

Diallel research may be used successfully to learn about the combining ability of a set arrangement of self-and cross-pollinated populations. To distinguish appropriate parents for utilizing in crossing programs, including the assessment of the parents for a progression of crosses, and for estimation of heterosis in chilli, should be possible effectively through 
diallel technique $[10,16]$. Heterosis breeding employing the diallel technique can guarantee an improvement in chilli productivity due to the existence of integral quality activities and the occurrence of a high degree of non-additives quality effects [17-19]. Essentially, the system of peppers raiser is to accumulate in specific qualities a solitary cultivar with higher hereditary possible such as productivity, disease resistance, and bioactive compounds.

The objectives of this manuscript are to present the recent state-art techniques which have been practiced for the hereditary improvement of chilli and especially to assess the scope of heterosis for improvement in chilli genetically by the researchers. By investigating this successive information, the future experiment could be intended to create improved chilli cultivars with alluring high yielding attributes and quality too. Thus, the productivity of chilli will increase to overcome shortfalls due to adverse ecological conditions.

\section{Global Production Scenario of Chilli}

Over the last 20 years (1997-2017, www.fao.org/faostat accessed on 15 March 2021), global pepper production has grown substantially, from 2 to about 4.5 million tonnes of dried kinds and from over 17 to 36 million tonnes of fresh types. A similar trend was observed in the harvested area, with a 35 percent rise in the surface cultivated area in the previous 20 years, reaching around 3.8 million hectares presently. South Asia is the most concentrated chilli area of the world, representing around $55 \%$ of total world production. India is the largest contributor to around 38\%, followed by China at $7 \%$ while Pakistan, Peru, and Bangladesh contributed the same as 5\% (Figure 1). Fresh pepper is grown in 126 countries throughout the world, according to current statistics. China is the world's largest chilli producer, with an annual production of over 18 million tonnes, and Mexico with an annual production of 3.5 million tonnes (www.faostat.fao.org accessed on 6 January 2019). The production of dry pepper is in 70 nations and there is no corresponding output in Oceania. With around 2.0 million tonnes, India is the biggest producer followed by Thailand (349.615 tons). Peppers are produced anywhere in the world and are often easy for farmers or in a greenhouse under various conditions. As far as dry pepper is concerned, Asia and Africa provide a contribution of $70.3 \%$ and $21.2 \%$ to the overall global output, respectively, while $67.3 \%$ and $10 \%$ for fresh pepper (Figure $2 \mathrm{~A}, \mathrm{~B}$ ). The economic value of pepper production has been increasing since 1991, making it a lucrative source of revenue for farmers in many nations and an essential element of global trade. The current value of dry pepper is $\$ 3.8$ trillion, compared to fresh pepper of $\$ 30.208$ trillion. In both instances, the increase in dried pepper and fresh pepper grew four times and six times, respectively, in the last 25 years. The largest importers include the USA with over $24 \%$, Malaysia with $12 \%$, and Sri Lanka with $9 \%$ of global imports. Spain was the largest chilli exporter of 1140 million USD which is $26 \%$ of the total followed by the The Netherlands (1100 million USD) holed by $25 \%$ (Figure 3A) however, maximum production was recorded for Spain as $22.4 \%$ and next to The Netherlands as $21.6 \%$ of the total world production (Figure $3 \mathrm{~B}$ ).

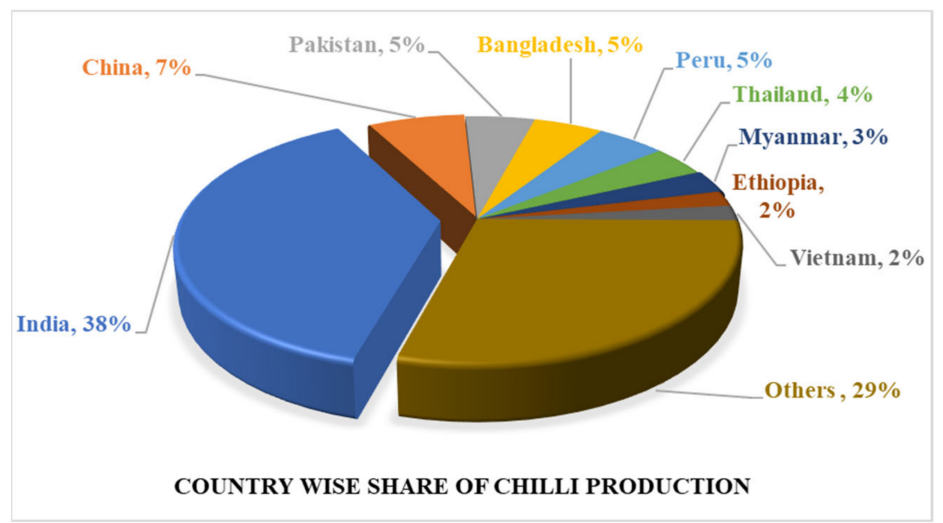

Figure 1. Country-wise share of chilli production extracted from www.faostat.fao.org (accessed on 6 January 2019). 


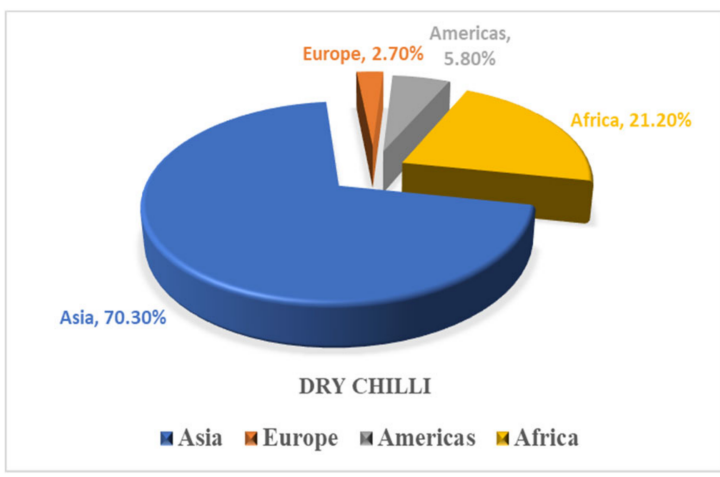

(A)

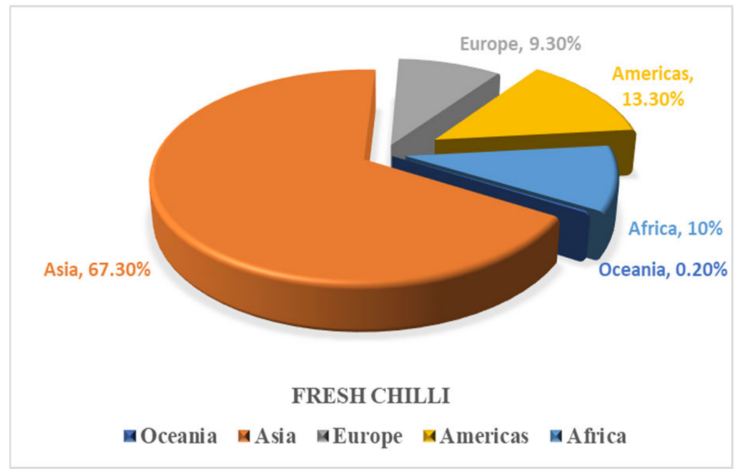

(B)

Figure 2. Dry (A) and fresh (B) pepper production by area (www.faostat.fao.org, accessed on 6 January 2019).
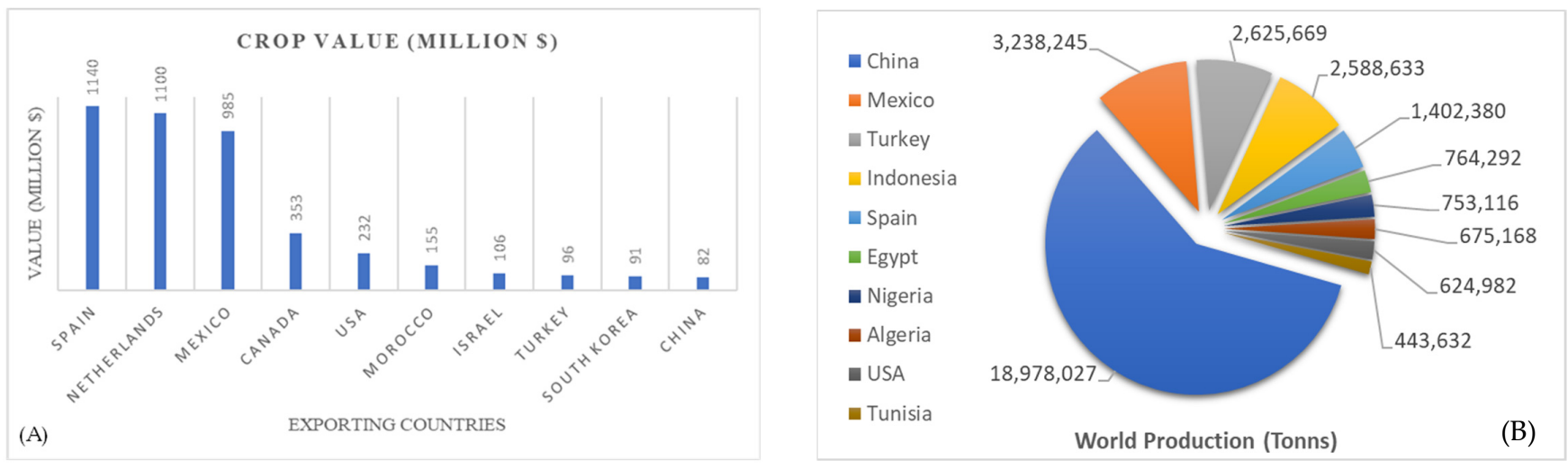

Figure 3. The 10 largest exporters of sweet and chilli pepper: (A) crop value in million USD, and (B) production (FAOSTAT, 2019).

\section{Genetic (Germplasm) Resources and Their Ancestry}

Among the other cultivated crops of the Western Hemisphere, the Capsicum pepper can be mentioned as one of the oldest domesticated plants. Different ethnic groups all over the world are using this as an important spice [19,20]. In the earlier period before Columbus reached in Americas during the 14th century, chilli peppers were used as food, as war artifacts, and in spiritual customs by different indigenous people [21]. Domestication began with wild Capsicum species in various parts of Mexico, Central America, and South America. Before domestication, approximately 7200 years ago, such wild varieties were used in human nutrition, not only as a spice but also as a source of food [22]. Peppers were also thought to have magical and mystical properties by ancient cultures. It was extremely important in Aztec, Mayan, and Inca societies, and the fruit was consumed on an empty stomach to cure fevers and to honor the gods [5]. Chilli peppers were produced and picked for a variety of reasons, revealing that Native Americans were the most prolific "pepper growers". They used many types of peppers that are being cultivated today. Of course, plant breeding was slow and unplanned, relying heavily on the art of entity selection. Nevertheless, what was formerly seen as art became science based on Mendel's genetics and hereditary ideas. In-plant breeding (including chilli peppers) there are now various selection procedures, and this depends primarily on the intended goal and plants used as a parent [23]. Essentially, a pepper breeder's goal is to collect all of the essential characteristics in a single cultivar, such as increased genetic potential, high productivity, disease resistance, and bioactive chemicals, among others.

The World Vegetable Center (WVC), Tainan, Taiwan, and the United States Department of Agriculture (USDA) in Griffin, Georgia are two of the world's main collections of Capsicum germplasm. In addition to the WVC and the USDA, there are other major 
collections in Costa Rica, Mexico, Brazil, The Netherlands, and Germany [1]. In 1986 Capsicum species were recognized as a primary crop category within the center by the World Vegetable Center (WorldVeg). The collection of the World Vegetable Center (WorldVeg) (WVC) had at the time 286 Capsicum adhesion and in the following years, the collection increased substantially. The WVC and the USDA have active collections of 8264 and 4953 accessions, respectively (Table 1). Accessions that have yet to be classified are included in these data also. The domesticated taxa including C. annuum L., C. baccatium L., C. chinense, C. frutescens $L$. and C. pubescens are more than 99 percent of identified materials. In both collections, the Capsicum annuum is the dominating taxon. Capsicum pubescens is represented very slowly and wild crop very small amounts to just one percent of all assets. Materials from more than 100 nation are represented in the WVC and the USDA collections. The Genetic Resources Information Network offers characterization and assessment data, passport information, and digital pictures of gene bank assets (https: / Www.grin-global. org accessed on 15 August 2018), and the WVC Genetic Resources Information System (World Vegetable Center: Home, https:/ / avrdc.org, databases accessed on 12 May 2021). The collected germplasm can be used for the source of the chosen gene to develop new genotypes with desirable traits [23]. Notable genetic resource centers in the world engaged in the collection, maintenance, and development of genetic resources/varieties of different Capsicum species [24] are listed in Table 1 below.

Table 1. List of resources and germplasm databases of Capsicum adopted from Chhapekar et al. [24], (Publisher: Daya Publishing House, 2016).

\begin{tabular}{|c|c|c|c|}
\hline Institute & Country & Description & Web \\
\hline $\begin{array}{c}\text { Banco de Germoplasma de } \\
\text { Hortaliças (BGH) }\end{array}$ & Brazil & $\begin{array}{c}\text { By providing BGH text in the name } \\
\text { field, you may monitor BGH's of } \\
\text { various collections in the Chileman } \\
\text { data base. }\end{array}$ & $\begin{array}{l}\text { http:/ / www.thechileman.org/ } \\
\text { search.php (accessed on } 6 \text { June 2020) }\end{array}$ \\
\hline $\begin{array}{l}\text { The Centre for Genetic } \\
\text { Resources, The Netherlands } \\
\text { (CGN)) }\end{array}$ & $\begin{array}{l}\text { The } \\
\text { Netherlands }\end{array}$ & $\begin{array}{c}\text { In all, } 1009 \text { accessions are available } \\
\text { with the Institute for enhanced } \\
\text { disease resistance and harvest } \\
\text { features. The CGN species are listed } \\
\text { in the Chileman database as well and } \\
\text { may be found in the database by } \\
\text { typing CGN text. }\end{array}$ & $\begin{array}{l}\text { http: / / applicaties.wageningenur. } \\
\text { nl/applications/ cgngenis / } \\
\text { ZoekGewas.aspx?ID=pzlo0t45 and } \\
\text { Cropnumber=38 OR http:/ / www. } \\
\text { thechileman.org/ search.php } \\
\text { (accessed on 16 August 2019) }\end{array}$ \\
\hline $\begin{array}{l}\text { The Chile Pepper Institute } \\
\text { (New Mexican State } \\
\text { University) }\end{array}$ & Mexico & $\begin{array}{l}\text { An elite institute having maximum } \\
\text { genetic resources, germplasm } \\
\text { collection of different } \\
\text { Capsicum species }\end{array}$ & $\begin{array}{c}\text { http: } \\
\text { / / www.chilepepperinstitute.org } \\
\text { OR http:/ / www.thechileman.org/ } \\
\text { search.php } \\
\text { (accessed on 6 June 2020) }\end{array}$ \\
\hline $\begin{array}{l}\text { The German Research } \\
\text { Centre for Biotechnology } \\
\text { (CAP) }\end{array}$ & Germany & $\begin{array}{l}\text { Many of its variations may be } \\
\text { discovered in the Chileman database } \\
\text { by typing the CAP in the name box }\end{array}$ & $\begin{array}{l}\text { http:/ / www.thechileman.org/ } \\
\text { search.php } \\
\text { (accessed on 6 June 2020) }\end{array}$ \\
\hline $\begin{array}{l}\text { United States Department } \\
\text { of Agriculture Research } \\
\text { Service (USDA) }\end{array}$ & USA & $\begin{array}{l}\text { They are having most extensive } \\
\text { Capsicum genotype collections (4953), } \\
\text { resistant to different diseases. }\end{array}$ & $\begin{array}{c}\text { http:/ / www.ars-grin.gov/npgs/ } \\
\text { acc/acc_queries.html } \\
\text { (accessed on 20 January 2020) OR } \\
\text { http:/ / www.thechileman.org/ } \\
\text { search.php (accessed on } 6 \text { June 2020) }\end{array}$ \\
\hline
\end{tabular}

A collection (8264) of several

The World Vegetable Center (WorldVeg) (WVC)
Taiwan
Capsicum species resistant to different diseases especially viral with accession number, characterization, and evaluation data. http:/ / www.avrdc.org (accessed on 26 June 2019) 
Table 1. Cont.

\begin{tabular}{|c|c|c|c|}
\hline Institute & Country & Description & Web \\
\hline $\begin{array}{l}\text { National Bureau of Plant } \\
\text { Genetic Resources }\end{array}$ & India & $\begin{array}{l}\text { A collection of germplasm of different } \\
\text { Capsicum species with accession } \\
\text { number, characterization, and } \\
\text { evaluation data }\end{array}$ & $\begin{array}{l}\text { www.nbpgr.ernet.in/pgrportal } \\
\text { (accessed on } 6 \text { September 2020) }\end{array}$ \\
\hline $\begin{array}{c}\text { ECPGR Pepper Database, } \\
\text { Aegean Agricultural } \\
\text { Research Institute, AARI }\end{array}$ & Turkey & $\begin{array}{l}\text { A collection of germplasm of } \\
\text { different Capsicum }\end{array}$ & $\begin{array}{c}\text { http:/ / www.etae.gov } \\
\text { (accessed on } 10 \text { November 2018) }\end{array}$ \\
\hline The Chile variety database & & $\begin{array}{l}\text { A collection of a large number of } \\
\text { variants resistant to most diseases } \\
\text { and nematodes }\end{array}$ & $\begin{array}{l}\text { http:/ / www.g6csy.net/chile/ } \\
\quad \text { database.html } \\
\text { (accessed on } 10 \text { February 2020) }\end{array}$ \\
\hline
\end{tabular}

\section{General Purposes and Classical Breeding Techniques Used for Capsicum Improvement}

\subsection{Common Goal for Capsicum Breeding}

In chilli breeding, the breeders typically have major goals (Figure 4) with features such as production, disease, and pest resistance, fruit traits (bioactive chemicals, fruit color, pungent color, flavor), and abiotic stressors (salinity, drought, coldness, and heat) [21]. There are four main macro-objectives of chilli breeding and they are related to (a) key agronomies such as yield, color, and shape, plant habit and fruit; (b) the abiotic stress resistance, such as drought and salinity, limiting cultivation in certain regions, (c) bacteriumlike, fungal and viral disease resistance, leading to severe damage to production and quality loss, and (d) quality which has a focus on the development of different bioactive substances such as capsaicinoids, isoprenoids, flavonoids, and vitamin C. for breeding goals [8].

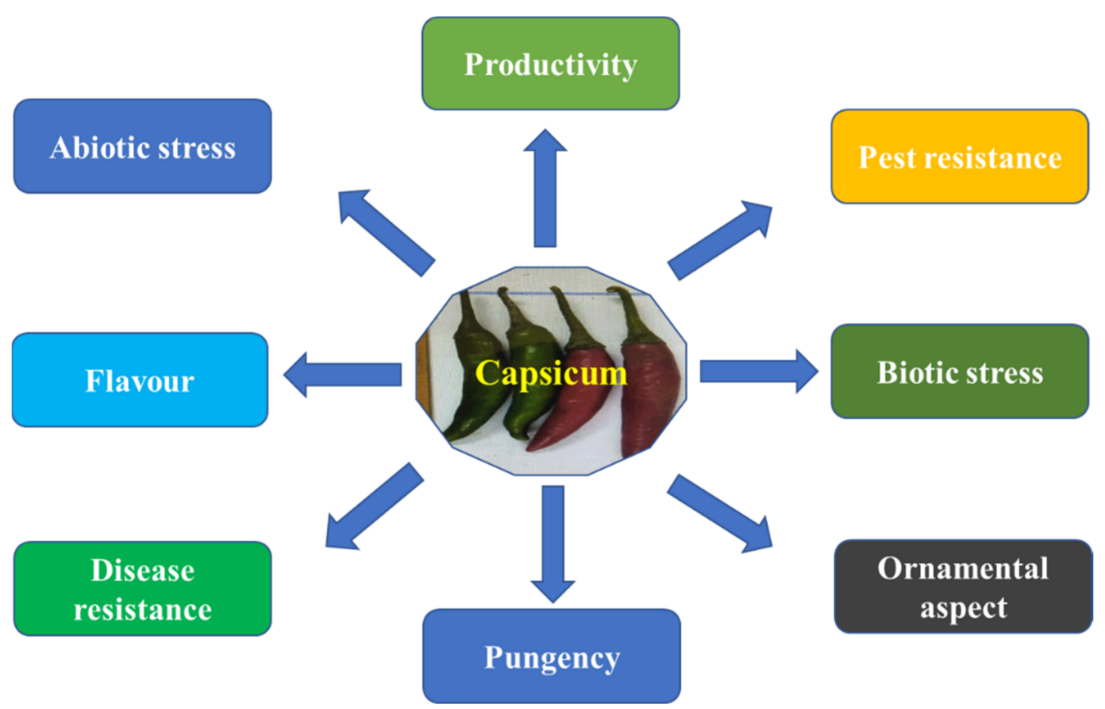

Figure 4. The primary objectives of breeding initiatives for chilli peppers were adopted from [25].

All over the world breeders are continually trying to develop the hottest pepper that overcomes previously launched one. As a result, one of the major focuses in breeding agendas is to find the hottest chilli. Commercial breeders also use techniques to obtain hybrid increasingly hot for-profit and advertisement [24]. Currently, consumers are looking for ornamental peppers also in the market. Various European countries such as Germany, for example, have utilized these plants extensively to beautify landscapes and researching to better understand the physiology of this plant to improve aesthetic features [21]. Thus, the breeders are setting their goals to meet the market demands. There is a list of known characteristics that pepper raisers must possess. 


\subsection{Classical Breeding Techniques Used for Chilli Improvement}

Chilli germplasm exhibits a wide range of variability. In accessions of gene banks, new sources of genetic diversity can be identified to obtain desirable genotypes. However, they must be correctly described to make their usage easy. Cultivars with high compound levels which play an important role in consumer health should be developed by breeders. [25-27]. Peppers (Capsicum spp.) are largely self-pollinated and diploid plants. Male and female regenerative parts are present in the Capsicum genotype as an ideal flower. They are inextricably linked to Solanaceae plants such as potato, tomato, eggplant, tobacco, and petunia. Despite the drastic change in genome size, all individuals in this family have a relatively large number of chromosomes in the genotype $(2 n=2 x=24)$. There are some wild species that have chromosome number $2 n=2 x=26$. The size of the $C$. annuum genome $(3.48 \mathrm{~Gb})$ at the assembled level is about three times more than that of the tomato. The typical exon/intron length is $286.5 \mathrm{bp} / 541.6 \mathrm{bp}$, genes are around 34,900 and translated portions are $2.34 \mathrm{~Gb}$ in total $(76.4 \%)$. The hot pepper's genome was divided into several syntenic blocks with the tomato genome, its next relative in the Solanaceae family [20].

The Capsicum's description began in 1965 with 50 characteristics. Currently, there are 292 different characteristics, for example dw-1 (dominate plants 15 to $20 \mathrm{~cm}$ tall), Ef (early flowering), me-2 (Meloidogyne spp.), and others. Table 2 displays the fundamental methods used in the breeding of chilli peppers. The most often utilized cultivar improvement procedures [26,28-32] include mass selection, pedigree (or genealogical) system, Single Seed Descent-SSD technique, backcross, selection of recurrent products, and hybridization's ideal technique or a mix of strategies relies on how the features to be enhanced are inherited (monogenic, oligogenic or polygenic) [33]. The following is a brief description of the situation.

\subsubsection{Mass Selection}

In ancient times the indigenous peoples of tropical America used Mass Selection effectively, collecting seeds from the best plants to be used in the following planting season. This technique can be utilized in circumstances when the traits are evident to identify populations with genetic variety and high heritage potential [32]. Conventional and Contemporary Approaches to Enhance Efficiency in Breeding Chilli/Hot Pepper [33]. This technique can also be used for the overall improvement of chilli especially for the genetic stock which will be used in breeding programs [34,35].

\subsubsection{The Pedigree Method}

The pedigree approach is followed by documentation of the cross and its offspring. This is carried out through the selection and self-pollination of individual plants. In the segregation and hybridization process, the superior variations are selected amongst superior plants together with the preservation of pedigree records [36]. The magnitude of heritable, and more particularly genetic components, is the most important aspect of the genetic constitution of the breeding material, which has a close bearing on its response to selection [37].

\subsubsection{Single Seed Descent Method}

In this approach, the selection is not carried out during the breeding process and recombinant inbred lines (RILs) are utilized in the development procedure. Advancement of generations can be performed in a controlled environment [28] to obtain lines resistant to various biotic stress. The biotechnological technique can be used in combination with conventional methods such as single seed descent (SSD), which allows homozygous lines and/or recombinant inbred lines to be obtained in a relatively short time [38,39].

\subsubsection{Recurrent Selection}

Individuals are selected from a distinct population, followed by crossings [23]. The original stock of seed is space-planting and superior seedlings chosen and separately 
harvested. As a result, each offspring of the plant is developed and progeny displaying higher output is bulk collected and subsequently tested in repeated testing with control cultivars. This procedure can help to select the recombinant more accurately compared to other methods [40].

\subsubsection{Backcross}

The traits which are controlled by one or a few genes can be improved by using the backcrossing technique, which involves selecting individual plants and successive crosses to a recurrent parent $[5,29]$. This has been an essential method for introgression genes from interspecific crosses. For fruit quality, disease resistance, or any other specific attribute a pure line can be improved by backcrossing to incorporate novel genes [30]. The gene-controlling resistance may contribute to the development of an improved chili variety and speed up the selection process, while also reducing genetic drag in the segregating population $[40,41]$.

Table 2. Major traditional approaches are employed in programs of Capsicum breeding.

\begin{tabular}{ccc}
\hline Name of the Approaches & Assumption & Reference \\
\hline Mass selection & $\begin{array}{c}\text { The next growing year stored seeds of } \\
\text { the finest plants; the oldest technique }\end{array}$ & [42] \\
Pedigree method & $\begin{array}{c}\text { Maintaining matings records and } \\
\text { progenies. This comprises the selection } \\
\text { and self-pollination of single plants. }\end{array}$ & [43] \\
SSD (Single seed descent) & $\begin{array}{c}\text { This approach involves advances } \\
\text { also used for the production of } \\
\text { recombinant inbred lines. }\end{array}$ & [28] \\
Recurrent selection & $\begin{array}{c}\text { Keep choosing individuals from a } \\
\text { population and then crossing across to } \\
\text { establish a new population. }\end{array}$ & [44] \\
\hline Backcross & $\begin{array}{c}\text { Especially for characteristics regulated } \\
\text { by one or few genes involving the } \\
\text { selection of individual plants and } \\
\text { subsequent crossings for } \\
\text { recurring parents }\end{array}$ & {$[29]$} \\
\hline Hybridization & $\begin{array}{c}\text { From one species genes or variations } \\
\text { migrate via the crossover process }\end{array}$ & [42]
\end{tabular}

\subsubsection{Hybridization}

Hybridization is a key element in plant evolution because it provides novel genetic combinations. Single selection techniques can be used to improve most traits which are regulated both by additives and non-additives genes [32]. It may be possible to introduce an introgressive hybridization when one species' genes transfer into another by an intersectoral hybrids process, and one parent passes successively. For example, in C. chinense PBC932 resistance has been passed on to C. annuum by traditional backcross [42] successfully at the AVRDC-World Vegetable Center-Taiwan. A new plant variety can be developed depending on the right approach. The Chilli flowers are structured in full, have calyx, corolla, sex organs for men and women. Through the manual emasculation method and subsequent pollination or utilizing the male sterility system [32], hybrid plants can be generated. Due to the difference between sex organs, the manual emasculation procedure is relatively straightforward. The technique consists of eliminating the male component and retaining the female structure (stigma). The breeder carries out crossings and puts the pollen from the plant that is used as the male parent in floral plant stigma used as mother [23]. A flower receiving pollen will be emasculated before this transaction 
to prevent contamination by the pollen itself. The crossing flora is covered with a label and prevents pollination by insects by contaminating foreign pollen.

\subsubsection{Genetic Basis of Hybridization}

Both intergeneric and interspecific are the two most prevalent sex types of hybridization. Interspecific hybridization happens where two species cross-fertilize, whereas intergeneric hybridization is produced with two species cross-fertilizing, which results in both parent phenotypes, genotypes, and development of the offspring [31]. Plant hybrids are created when the pollen from one kind of plant is used to pollinate an entirely different variety, resulting in a new plant altogether often known as first filial generation (F1) [32]. A typical hybridization method for Capsicum breeding is displayed in Figure 5 [33]. The difference in productivity between the hybrids and the mean of the parental genotype is characterized as the mid-parental heterosis. The better parent heterosis is defined [33] as a greater or better parental production. It is used to enhance vigor and produce more variability in cultivar growth. The chance of success in the production of hybrids is $15-25 \%$ greater than natural pollination. [35]. A hybridization to create improved segregants in the segregated hybrid community is necessary to find or locate the greatest feasible pairing of two or more ancestral genotypes to maximize variance in such a population [34]. Many breeding schemes were used for the assessment of general combining capacity (GCA) and specific combining capacity variations (SCA) for Solanaceae [31]. The GCA and SCA methods for quantitative genetic approaches for the determination of the characteristics and the ability to combine parental genes to generate the economically suitable plant attributes [36]. In describing hybrid development [34], the over-dominant concept of plant genetic might be employed. Over-dominantly, heterogeneous loci alloys exceed homogeneous parents, which refers to the use of the higher features in F1 in comparison to their predecessors. Heterosis or hybrid vigor is affected by a combination of genotypes, epigenetics, morphology, and ecology [33].

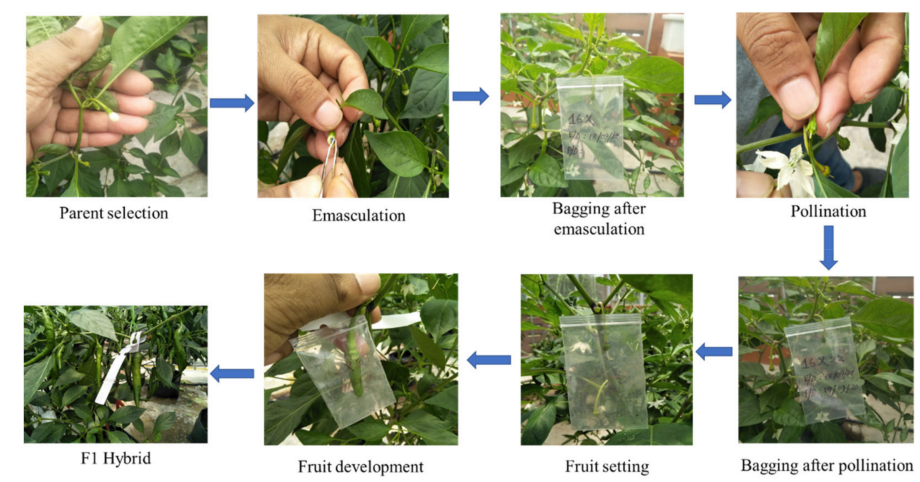

Figure 5. The technique of hybridization: In the previous evening before the flowers were opened, the desired flowers which were to be pollinated the next morning will be emasculated and covered with a plastic bag. On the following morning, the pollen of the targeted flowers was dusted on the female part and covered to avoid unwanted cross-pollination. Details about parents and pollination date have been put on a label. (Picture captured from author's research field).

\subsection{Using the Male Sterile Lines}

Manual emasculation techniques are time-consuming and costly when hybrid seed production of peppers is commercially practiced. An alternative for solving this problem is to use male sterility. The Capsicum has been documented for both genital and cytoplasmic male infertility. In hybrid seed production, functional male sterility can be effectively used. Male sterility is therefore one of the main characteristics exploited in hybrid breeding [34]. The natural, spontaneous mutations or the effect of mutagenic agents might be shown as male sterile in peppers. For hereditary male sterility, more than 20 genes were identified genic male sterility (GMS). The use of male sterile lines as parents can therefore be an 
alternative to reducing costs. The experimental and commercial basis for hybrid seed business is widely utilized for men's sterility, genicity, and cytoplasmic male sterility (CMS) sources $[23,43]$.

The phenotypic selection of superior individuals from segregating populations is the major part of the conventional plant breeding approach. To breed a new/improved variety takes time, often between 8 and 12 years and even then, the release of improved variety is not guaranteed. The two principal limitations of the conventional approach are. The number of generations, and thus time. Therefore, to overcome the problem, it is wise to use modern approaches along with conventional ones.

\section{Use of Heterosis for Targeted Genetic Breeding with Specific Traits}

\subsection{Heterosis for Crop Improvement}

Heterosis has been widely applied to a large number of crop species for their improvement to increase yield, quality, and adaptability of hybrids [45,46]. Hybrid varieties are being developed to exploit hybrid vigour. Hybrid vigour is the increase in size, vigour, fertility, and overall productivity over the mid-parent value. Heterosis was coined by G.H. Shull as a synonym of hybrid vigor [47]. Heterosis indicates the excellence of the F1 generation over their parents. An increase of F1 values over their parents is considered heterobeltiosis. An increase of F1 value over commercial variety/hybrid is designated as standard heterosis. Identification of crosses with a high degree of positive heterosis is the basic requisite in hybrid variety development [46].

\subsection{Basis of Heterosis}

Inbred lines consist of homozygous genotypes are developed as parents in the production of hybrid varieties and synthetic cultivars in the breeding of cross-pollinated species [48]. Factors that give effects on the expression of heterosis are heterozygosity, between locus interaction or epistasis, allelic interaction, maternal interactions, and dominance or overdominance [49]. There are three types of inbred lines, namely, conventional or normal inbred, non-conventional inbred, and genetically modified inbred lines $[9,50]$. A successful breeding program usually depends on properly selecting inbred lines with genetic diversity and combining ability analyses [11]. The breeding value of the inbred lines is estimated based on the heterosis when combined with other lines. Therefore, it is very important to evaluate the superior progenies when combinations with another line [51]. The superiority of inbred lines does not depend only on their greater per se performance but on their capacity to transmit genes that are responsible for economic traits to their progenies [52]. Diallel, partial diallel, and line $\times$ tester analyses are the common biometrical techniques used for the estimation of combining ability of inbred lines [53]. Diallel is one of the popular analytical methods used for the evaluation of genetic stock before using it in a hybridization program to identify good general and specific combiners $[44,54]$. The analysis helps to estimate the general combining ability (GCA) effects of inbred lines, specific combining ability (SCA) effects of crosses, the relative proportion of additive and non-additive genetic variance, and narrow-sense heritability [44].

\subsection{Desired Traits of Interest Associated with Chilli}

Knowledge on combining the ability of parents and the gene effect involved in the inheritance of different traits are prerequisites to the initiation of any crop improvement program [55]. Combining ability of a genotype/inbred line is the capacity to transfer superior performance to its crosses [55]. Estimates of combining ability of inbred lines indicate the way for further scientific footing in heterosis breeding and chilli has much scope for improving the yield and other economic traits through heterosis breeding $[11,15]$. Combining abilities are of two types, namely general combining ability (GCA) and specific combining ability (SCA). The GCA is mostly due to additive gene action and the SCA is due to non-additive gene action [56]. To identify suitable parents in hybridization both SCA and GCA variances are important [55]. Studies on GCA and SCA of inbred lines 
revealed that the nature of gene action in the expression of a particular trait and it helped to identify superior crosses from a parental combination [36]. Kaur et al. [48] recorded significantly high GCA and SCA in chilli for the traits such as days to flowering, total yield, early yield, fruit length, fruit weight, plant height, pericarp thickness, number of seeds per fruit, and 1000-seed weight. According to Jindal et al. [57], significant positive GCA and SCA were also observed for dry matter content, ascorbic acid content, oleoresin content, and capsaicin content. Fruit length, days to flowering, fruit yield, early yield, number of fruits per plant, number of seeds per fruit, and average fruit weight have also been recorded to have significant desirable GCA [43]. Impacts such as early yield, fruit length, fruit diameters, pericarp thicknesses, and plant number of fruits were also observed with significant positive SCA effects.

The GCA and SCA variance observed in chilli was notable for traits such as first flowering, the number of branches for plant and plant, days to last picking, crop height, fruit length, seed numbers per fruit, fruit diameter, fruit diameter, and plant number, green fruit yield per crop, fruit yield per crop, fruit yield per plant, and capsaicin containment. Navhale et al. [58]. The most significant economic feature of the chilli is fruit yield [59].

\subsection{Utilization of Heterosis in Recent Chilli Breeding Program}

Studies on GCA and SCA of inbred lines in chilli for its economic traits have been conducted by many researchers [49]. Analysis of the combining ability of inbred lines in chilli breeding programs provides information on inbred-line selection, identification of heterotic pattern, classification of heterotic groups for hybrid development [11].

\subsection{Heterosis through Molecular Approaches}

A large number of quantitative trait loci that contribute to heterosis have been discovered from genetic analysis of $F_{1}$ hybrids in maize, canola, and rice [60]. The molecular basis of heterosis in chilli has not been comprehensively discussed. Works on the identification of quantitative trait loci (QTLs), gene-based markers, and genome sequencing of chilli have been continued. QTL mapping has been undertaken for various yield-related traits. Dwivedi et al. [61] identified 10 QTLs for yield-related traits, the number of fruits/plants, ten-fruit weight, fruit width, pericarp thickness, and total fruit weight. Various molecular marker approaches in chilli have been applied to develop gene-based markers. Hill et al. [62] used genome-wide transcript-based markers to determine genetic and genomic features among 40 diverse $C$. annuum lines. The next-generation sequencing technique has been applied on chilli as a powerful tool for transcriptome analysis, gene functional annotation, and to identify molecular markers for marker-assisted selection and other genetic studies [63]. Scientists started the application genome sequencing of chilli species beginning of 2014. Later on, the genomic sequence of Chiltepin (C. annuum var. glabriusculum) was reported as C-annuum, Zunla-1, and wild species [64]. Both investigations have documented a 3-3.5 Gb genome size with about 35,000 genes [65,66].

\section{Future Projections}

The breeding of hybridizations is focused on the morphological expression of the plant rather than genotypic attributes. The process is time-consuming, labor-intensive, intimately linked, and may transfer unwanted genes alongside desired ones. In addition, genetic degradation, genetic dragging, and reproductive problems might impede conventional breeding processes. With the growth of the human population, the decreasing inputs (land, water), and the obvious decreasing yield curves, the world food need is no longer met by conventional breeding alone. As a result, the future re-investigation of cultivation requires the combination of the most traditional and new techniques of plant reproduction, such as bioinformatics, molecular biology and genes, genetic engineering, biometrics, mutational breeding, MAS, and genetic transformation as well as tissue culture. Taking into consideration the overall incidence, more ideas for improvement of the Capsicum are outlined here: 
1. Naturalized Capsicum requires nutrient analysis and medicinal uses. To benefit the local population in the areas of medical, nutrition, and economy, conventional food production techniques must be explored.

2. Governments, communities, business-people, and other stakeholders should work together to promote the popularization of native species of the land, by generating high-quality seeds to produce new kinds that are disease resistant and producing high yields.

3. An economic cost-benefit analysis of value-added alternatives should be carried out to determine which option would offer farmers the best margin of profit for their capsicum production.

4. The genetic variability in local species can be utilized to produce better, environmentally changeable Capsicum cultivars.

5. This expertise in the added value of Capsicum should be distributed to local citizens when it comes to surplus Capsicum production to decrease post-harvest waste, to the advantage of the overall socio-economic well-being of the farmers involved.

6. The Capsicum production and the many possibilities for Capsicum's added value, which might contribute to the possible sources of money and the general socioeconomic prosperity of both youth and women, must be encouraged and informed.

7. A comparative method to genomics can be employed to transmit the information about the genome from tomato to pepper and eggplant. The use of molecular markers in various crops is beginning to be significant. The Marker Assisted Selection (MAS) application can increase the performance, accuracy, and speed of conventional plant breeding significantly. MAS has become available to the Solanaceae breeders as the most potent molecular method for promoting crop advancements.Conventional breeding is still durable and easy in a long-term breeding program to produce a new variety, apart from employing contemporary technology.

8. So that this resistance source requires these lines may be successfully used against certain biotic stressors, greater attention should be focused on using wild relatives for the creation of pre-boring lines.

Furthermore, the above points emphasis should be given on:

- Evolution of less pungent and preferred kinds.

- The development of novel hybrids involving male sterility and chemical hybridization.

- Introduction of germplasm heat and dryness tolerance as a climate change approach.

- Set-specific varieties development.

- To create a variety, which can preserve the content of capsaicin after a prolonged time of storage.

- Species with greater levels of oleoresin and antioxidants developed.

\section{Conclusions}

Chilli has tremendous potential as a nutritionally and commercially important crop all over the world. The demand for this crop is increasing day by day. High variability present in nature for quality and yield contributing characters of Capsicum allows various researchers to demonstrate a good number of progress towards the genetic improvement of Capsicum. Moreover, there is a lot of sides to bring out through research by the breeders especially to synchronize this essential crop with the changing global environment. Heterosis breeding can be applied as an effective tool to improve the important economic traits of Capsicum. Proper exploitation of the male sterility system will pave the way for easy and more hybrid seed production cost-effectively. More applied research is the demand of time to address the global ecological change. Efforts should be taken to develop high yielding along with high antioxidant and oleoresin content varieties. Furthermore, disease-resistant and stress-tolerant cultivars should also be in consideration to combat the effect of climate change. The combination of conventional and molecular breeding could lead the breeders for developing sustainable capsicum cultivars to grow commercially by the farmers. The development of the Capsicum genotypes in terms of yield and quality might be one option 
to alleviate food and nutritional issues. These can be accelerated by engaging the research associated with combining ability, gene action, and heterotic vigor of diallel mating design as well as hybridization approaches. Moreover, the information gathered in this article will be able to add at least some momentum to the ongoing chilli research and for the future program as well.

Author Contributions: All authors contributed significantly to develop, procedure and writingreviewing and editing; K.M.R.K., investigation, visualization, writing-the original draft of the manuscript; editing and approval of the final version of the manuscript by M.Y.R., A.B.M., M.F.B.I., A.R.H., M.M.H.K. and M.F.N.C. All authors have read and agreed to the published version of the manuscript.

Funding: The first author was sponsored by the NATP Phase-II project of Bangladesh Agricultural Research Council (BARC) for his Ph.D. study. This study was sponsored by a grant from BARC (Grant number-6282502-10214).

Institutional Review Board Statement: Not applicable.

Informed Consent Statement: Not applicable.

Data Availability Statement: Not applicable.

Acknowledgments: The authors pay thanks to the Universiti Putra Malaysia (UPM) and Bangladesh Sugarcrop Research Institute (BSRI), the People's Republic of Bangladesh for their support.

Conflicts of Interest: The authors have no conflict of interest to publish this manuscript.

\section{References}

1. Jarret, R.L.; Barboza, G.E.; da Costa Batista, F.R.; Berke, T.; Chou, Y.-Y.; Hulse-Kemp, A.; Ochoa-Alejo, N.; Tripodi, P.; Veres, A.; Garcia, C.C.; et al. Capsicum-an abbreviated compendium. J. Am. Soc. Hortic. Sci. 2019, 144, 3-22. [CrossRef]

2. Colney, L.; Tyagi, W.; Rai, M. Morphological and molecular characterization of two distinct chilli cultivars from North Eastern India with special reference to pungency related genes. Sci. Hortic. 2018, 240, 1-10. [CrossRef]

3. Shetty, P.K.; Ayyappan, S.; Swaminathan, M.S. Climate Change and Sustainable Food Security; NIAS/ICAR: New Delhi, India, 2013.

4. De Vasconcelos, C.S. Recursos Genéticos de Pimentas (Capsicum, Solanaceae): Qualidade de Frutos Após a Colheita e Ação dos Compostos Antioxidantes na Prevenção da Síndrome Metabólica. Ph.D. Thesis, Universidade Federal de Pelotas, Pelotas, Brazil, 2016; pp. 1-114.

5. Bosland, P.W.; Votava, E.J.; Votava, E.M. Peppers: Vegetable and Spice Capsicums; CABI: Wallingford, London, UK, 2012.

6. Sokona, D.; Niamoye, Y.D.; Paul, N.S.; Olagorite, A.; Aminata, D.N.; Kadidiatou, G.T.; Aissata, T.T.R.; Sériba, K.; Daoulé, D.-B. Overview of pepper (Capsicum spp.) breeding in West Africa. African J. Agric. Res. 2013, 8, 1108-1114. [CrossRef]

7. Chowdhury, M.F.N.; Yusop, M.R.; Ismail, S.I.; Ramlee, S.I.; Oladasu, Y.; Hosen, M.; Miah, G. Development of anthracnose disease resistance and heat tolerance chili through conventional breeding and molecular approaches: A review. Biocell 2020, 44, 269-278. [CrossRef]

8. Moscone, E.A.; Scaldaferro, M.A.; Grabiele, M.; Cecchini, N.M.; Sánchez García, Y.; Jarret, R.; Ehrendorfer, F. The evolution of chili peppers (Capsicum-Solanaceae): A cytogenetic perspective. In Proceedings of the VI International Solanaceae Conference: Genomics Meets Biodiversity, Madison, WI, USA, 23-27 July 2016; pp. 137-170.

9. Tripodi, P.; Kumar, S. The Capsicum Crop: An Introduction. In The Capsicum Genome; Springer: Cham, Switzerland, $2019 ;$ pp. 1-8. [CrossRef]

10. Herath, H.M.S.N.; Rafii, M.Y.; Ismail, S.I.; Nakasha, J.J.; Ramlee, S.I. Improvement of important economic traits in chilli through heterosis breeding: A review. J. Hortic. Sci. Biotechnol. 2021, 96, 14-23. [CrossRef]

11. Bhutia, N.D.; Seth, T.; Shende, V.D.; Dutta, S.; Chattopadhyay, A. Estimation of heterosis, dominance effect and genetic control of fresh fruit yield, quality and leaf curl disease severity traits of chilli pepper (Capsicum annuum L.). Sci. Hortic. 2015, 182, 47-55. [CrossRef]

12. Nagaraju, M.M.; Kumary, I.S.; Celine, V.A.; Devi, C.R.S.; Manju, P. Development of F1 Hybrids in Chilli (Capsicum annuum L.) for Dual Purpose (Green as well as Dry). Int. J. Curr. Microbiol. Appl. Sci. 2017, 6, 84-96. [CrossRef]

13. Rohini, N.; Lakshmanan, V. Evaluation studies of hot pepper hybrids (Capsicum annuum L.) for yield and quality characters. Electron. J. Plant Breed. 2017, 8, 643-651. [CrossRef]

14. Sreenivas, M.; Sharangi, A.B.; Banerjee, S.; Kumar Maurya, P.; Bhattacharjee, T. Selecting Parental Lines among Genotypes of Capsicum annuum for Hybridization Aiming at Dry Fruit Yield Improvement. Int. J. Curr. Microbiol. Appl. Sci. 2019, 8, 1881-1899. [CrossRef]

15. Alok, C.; Rajesh, K.; Solankey, S.S. Estimation of heterosis for yield and quality components in chilli (Capsicum annuum L.). Afr. J. Biotechnol. 2013, 12, 6605-6610. [CrossRef] 
16. Singh, D.K.; Pramod, T.; Jain, S.K. Heterosis studies for growth, flowering, and yield of chilli (Capsicum annuum L.). Pantnagar J. Res. 2012, 10, 61-65.

17. Ganefianti, D.W.; Fahrurrozi, F. Heterosis and Combining Ability in Complete Diallel Cross of Seven Chili Pepper. AGRIVITA J. Agric. Sci. 2018, 40, 360-370. [CrossRef]

18. Hasanuzzaman, M.; Golam, F. Gene actions involved in yield and yield contributing traits of chilli (Capsicum annuum L.). Aust. J. Crop Sci. 2011, 5, 1868-1875.

19. Do Rêgo, E.R.; do Rêgo, M.M.; Finger, F.L.; Cruz, C.D.; Casali, V.W.D. A diallel study of yield components and fruit quality in chilli pepper (Capsicum baccatum). Euphytica 2009, 168, 275-287. [CrossRef]

20. Kim, S.; Park, M.; Yeom, S.-I.; Kim, Y.-M.; Lee, J.M.; Lee, H.-A.; Seo, E.; Choi, J.; Cheong, K.; Kim, K.-T.; et al. Genome sequence of the hot pepper provides insights into the evolution of pungency in Capsicum species. Nat. Genet. 2014, 46, 270-278. [CrossRef]

21. Chiou, K.L.; Hastorf, C.A.; Bonavia, D.; Dillehay, T.D. Documenting Cultural Selection Pressure Changes on Chile Pepper (Capsicum baccatum L.) Seed Size Through Time in Coastal Peru (7600 B.P.-Present). Econ. Bot. 2014, 68, 190-202. [CrossRef]

22. Padilha, H.; Barbieri, R. Plant breeding of chili peppers (Capsicum, Solanaceae)—A review. Aust. J. Basic Appl. Sci. 2016, 10, 148-154.

23. Sarath Babu, B.; Pandravada, S.R.; Prasada Rao, R.D.V.J.; Anitha, K.; Chakrabarty, S.K.; Varaprasad, K.S. Global sources of pepper genetic resources against arthropods, nematodes and pathogens. Crop Prot. 2011, 30, 389-400. [CrossRef]

24. Chhapekar, S.; Kehie, M.; Ramchiary, N. Advances in Molecular Breeding of Capsicum Species. Biotechnological Tools for Genetic Resources; Daya Publishing House: Darya Ganj, India, 2016; pp. 397-419. [CrossRef]

25. Hoffmann, A.M.; Noga, G.; Hunsche, M. Acclimations to light quality on plant and leaf level affect the vulnerability of pepper (Capsicum annuum L.) to water deficit. J. Plant Res. 2015, 128, 295-306. [CrossRef]

26. Baruah, S.; Zaman, M.K.; Rajbongshi, P.; Das, S. A Review on recent researches on Bhutjolokia and pharmacological activity of capsaicin. Int. J. Pharm. Sci. Rev. Res. 2014, 24, 89-94.

27. Padilha, H.K.M.; Pereira, E.D.S.; Munhoz, P.C.; Vizzotto, M.; Valgas, R.A.; Barbieri, R.L. Genetic variability for synthesis of bioactive compounds in peppers (Capsicum annuum) from Brazil. Food Sci. Technol. 2015, 35, 516-523. [CrossRef]

28. Ulhoa, A.B.; Pereira, T.N.; Silva, R.N.; Ragassi, C.F.; Rodrigues, R.; Pereira, M.G.; Reifschneider, F.J.B. Caracterização molecular de linhagens de pimenta do tipo Jalapeño amarelo. Hortic. Bras. 2014, 32, 35-40. [CrossRef]

29. Udaya Prakash, N.K.; Bhuvaneswari, S.; Sripriya, N.; Prameela, L.; Bhagya, R.; Radhika, B.; Balamurugan, A.; Arokiyaraj, S. Antioxidant activity of common plants of Northern Tamil Nadu, India. Int. J. Pharm. Pharm. Sci. 2014, 6, 128-132.

30. Negi, R.; Thakur, S.; Sharma, P. Advances in the Breeding of Bell Pepper-A Review. Int. J. Curr. Microbiol. Appl. Sci. 2018, 7, 2272-2281. [CrossRef]

31. Qin, C.; Yu, C.; Shen, Y.; Fang, X.; Chen, L.; Min, J.; Cheng, J.; Zhao, S.; Xu, M.; Luo, Y.; et al. Whole-genome sequencing of cultivated and wild peppers provides insights into Capsicum domestication and specialization. Proc. Natl. Acad. Sci. USA 2014, 111, 5135-5140. [CrossRef] [PubMed]

32. Norman, A.; Taylor, J.; Edwards, J.; Kuchel, H. Optimising genomic selection in wheat: Effect of marker density, population size and population structure on prediction accuracy. G3 Genes Genomes Genet. 2018, 8, 2889-2899. [CrossRef]

33. Rao, A.M.; Anilkumar, C. Conventional and Contemporary Approaches to Enhance Efficiency in Breeding Chilli/Hot Pepper. In Accelerated Plant Breeding; Springer: Cham, Switzerland, 2020; Volume 2, pp. 223-269.

34. Sthapit, B.; Shrestha, P.; Subedi, M.; Castillo-Gonzales, F. Mass selection: A low-cost, widely applicable method for local crop improvement in Nepal and Mexico. In Participatory Approaches to the Con-Servation and Use of Plant Genetic Resources; Friis-Hansen, E., Sthapit, B.R., Eds.; International Plant Genetic Resources Institute: Rome, Italy, 2000; p. 111.

35. Gosal, S.S.; Pathak, D.; Wani, S.H.; Vij, S.; Pathak, M. Accelerated Breeding of Plants: Methods and Applications. In Accelerated Plant Breeding; Springer: Cham, Switzerland, 2020; Volume 1, pp. 1-29.

36. De Sá Mendes, N.; Santos, M.C.P.; Santos, M.C.B.; Cameron, L.C.; Ferreira, M.S.L.; Gonçalves, É.C.B.A. Characterization of pepper (Capsicum baccatum) -A potential functional ingredient. LWT 2019, 112, 108209. [CrossRef]

37. Visalakshi, M.; Pandiyan, M. Crop improvement in chillies: An overview. Int. J. Chem. Stud. 2018, 6, 1736-1744.

38. Bermejo, C.; Gatti, I.; Cointry, E. In vitro embryo culture to shorten the breeding cycle in lentil (Lens culinaris Medik). Plant Cell Tissue Organ Cult. (PCTOC) 2016, 127, 585-590. [CrossRef]

39. Barroso, P.A.; Rêgo, M.M.D.; Crispim, J.G.; Costa, M.D.P.S.D.; Rêgo, E.R.D. How to shorten a plant breeding program? A case study with ornamental peppers. Crop. Breed. Appl. Biotechnol. 2019, 19, 193-199. [CrossRef]

40. Ridzuan, R.; Rafii, M.Y.; Ismail, S.I.; Mohammad Yusoff, M.; Miah, G.; Usman, M. Breeding for anthracnose disease resistance in chili: Progress and prospects. Int. J. Mol. Sci. 2018, 19, 3122. [CrossRef] [PubMed]

41. Do Rego, E.R.; do Rêgo, M.M.; Finger, F.L. Production and Breeding of Chilli Peppers (Capsicum spp.); Springer International Publishing: Cham, Switzerland, 2016; pp. 57-80.

42. Chen, J.; Luo, M.; Li, S.; Tao, M.; Ye, X.; Duan, W.; Zhang, C.; Qin, Q.; Xiao, J.; Liu, S. A comparative study of distant hybridization in plants and animals. Sci. China Life Sci. 2018, 61, 285-309. [CrossRef] [PubMed]

43. Goulet, B.E.; Roda, F.; Hopkins, R. Hybridization in plants: Old ideas, new techniques. Plant Physiol. 2017, 173, 65-78. [CrossRef] [PubMed]

44. Rodrigues, R.; Gonçalves, L.S.; Bento, C.d.S.; Sudré, C.P.; Robaina, R.R.; do Amaral, A.T., Jr. Combining ability and heterosis for agronomic traits in chili pepper. Hortic. Bras. 2012, 30, 226-233. [CrossRef] 
45. Nsabiyera, V.; Ochwo-Ssemakula, M.; Sseruwagi, P.; Ojiewo, C.; Gibson, P. Combining Ability for Field Resistance to Disease, Fruit Yield and Yield Factors among Hot Pepper (Capsicum annuum L.) Genotypes in Uganda. Int. J. Plant. Breed. 2013, 7, 12-21.

46. Awachar, A.V.; Pandey, M.K. Review on heterosis \& combining ability of Chilli. Int. J. All Res. Educ. Sci. Methods (IJARESM) 2021, 9, 2018-2022.

47. Singh, P.; Cheema, D.S.; Dhaliwal, M.S.; Garg, N. Heterosis and combining ability for earliness, plant growth, yield and fruit attributes in hot pepper (Capsicum annuum L.) involving genetic and cytoplasmic-genetic male sterile lines. Sci. Hortic. 2014, 168, 175-188. [CrossRef]

48. Ramesh, M.; Lavanya, C.; Sujatha, M.; Sivasankar, A.; Kumari, J.A.; Meena, H.P. Heterosis and Combining Ability for Yield and Yield Component Characters of Newly Developed Castor (Ricinus Communis L.) Hybrid. Bioscan 2013, 8, 1421-1424.

49. Rohini, N.; Lakshmanan, V. Heterobeltiosis and inbreeding depression for fruit yield and its components in hot pepper (Capsicum annuum var. annuum). Asian J. Hortic. 2016, 11, 86-92. [CrossRef]

50. Acquaah, G. Principles of Genetics and Plant Breeding. Classic Methods of Plant Breeding; Blackwell Publishing: Hoboken, NJ, USA, 2012; pp. 281-350.

51. Robsa Shuro, A. Review Paper on Approaches in Developing Inbred Lines in Cross-Pollinated Crops. Biochem. Mol. Biol. 2017, 2, 40. [CrossRef]

52. Kaur, D.; Jindal, S.K.; Dhaliwal, M.S.; Meena, O.P. Improving fruit traits in chilli pepper through heterosis breeding. Sabrao J. Breed. Genet. 2017, 49, 26-43.

53. Sharma, J.; Sharma, P.; Sharma, B.; Chaudhary, P. In-Vitro Estimation of Antioxidant Activity in Green Chilli (Capsicum annuum) and Yellow Lantern Chilli (Capsicum chinense). Int. J. Res. Rev. 2017, 4, 54.

54. Kaya, Y.; Balalic, I.; Milic, V. Eastern Europe Perspectives on Sunflower Production and Processing. In Sunflower; AOCS Press: Urbana, IL, USA, 2015; pp. 575-637.

55. Thilak, J.C.; Pant, S.C.; Veena, A.M.; Paliwal, A. Studies on general vs. specific combining ability estimates from diallel analysis for yield and its component traits in chilli (Capsicum annuum L. var. acuminatum). Int. J. Chem. Stud. 2019, 7, $1747-1749$.

56. Singh, P. Genetic distance, heterosis and combing ability studies in maize for predicting F1 hybrid performance. Sabrao J. Breed. Genet. 2015, 47, 21-28.

57. Griffing, B. Concept of General and Specific Combining Ability in Relation to Diallel Crossing Systems. Aust. J. Biol. Sci. 1956, 9, 463. [CrossRef]

58. Ahmed, N.; Hurra, M.; Wani, S.A.; Khan, S.H. Gene action and combining ability for fruit yield and its component characters in sweet pepper (No. Research). Capsicum Eggplant Newsl. 2003, 22, 55-58.

59. Janaki, M.; Babu, J.D.; Naidu, L.N.; Ramana, C.V.; Rao, C.K.K.; Krishna, K.U. Combining ability studies for yield and yield components in chilli (Capsicum annuum L.). Electron. J. Plant Breed. 2017, 8, 825. [CrossRef]

60. Patil, M.Y.; Sawant, G.B.; Jadhav, S.M. Combining ability and gene action studies in chilli (Capsicum annuum L.). Environ. Ecol. 2018, 36, 52-56.

61. Jindal, S.K.; Kaur, D.; Dhaliwal, S.; Chawla, N. Combining ability and heterosis for qualitative traits in chili pepper (Capsicum annuum L.). Int. J. Hortic. 2015, 5, 1-13.

62. Ajith, P.M.; Manju, P. Genetic Parameters and Character Association for Yield and Anthracnose Resistance in Chilli (Capsicum annuum L.). Int. J. Agric. Innov. Res. 2015, 4, 1473-2319.

63. Fujimoto, R.; Uezono, K.; Ishikura, W.; Osabe, K.; Peacock, W.J.; Dennis, E.S. Recent research on the mechanism of heterosis is important for crop and vegetable breeding systems. Breed. Sci. 2018, 68, 145-158. [CrossRef]

64. Dwivedi, N.; Kumar, R.; Paliwal, R.; Kumar, U.; Kumar, S.; Singh, M.; Singh, R.K. QTL mapping for important horticultural traits in pepper (Capsicum annuum L.). J. Plant Biochem. Biotechnol. 2015, 24, 154-160. [CrossRef]

65. Hill, T.A.; Chunthawodtiporn, J.; Ashrafi, H.; Stoffel, K.; Weir, A.; Van Deynze, A. Regions Underlying Population Structure and the Genomics of Organ Size Determination in Capsicum annuum. Plant Genome 2017, 10, 3-14. [CrossRef] [PubMed]

66. Ahn, Y.-K.; Tripathi, S.; Cho, Y.-I.; Kim, J.-H.; Lee, H.-E.; Kim, D.-S.; Woo, J.-G. Molecular marker information from de novo assembled transcriptomes of chilli pepper (Capsicum annuum L.) varieties based on next-generation sequencing technology. Plant Genet. Resour. 2014, 12, S83-S86. [CrossRef] 